\title{
Pediatric oral ranula: Clinical follow-up study of 57 cases
}

\author{
Cristina Bonet-Coloma ${ }^{1}$, Ignacio Minguez-Martinez ${ }^{2}$, Amparo Aloy-Prósper ${ }^{3}$, Sonnica Galán-Gil ${ }^{4}$, Mary \\ Peñarrocha-Diago ${ }^{5}$, Juan-Manuel Mínguez-Sanz ${ }^{6}$
}

\footnotetext{
${ }^{1}$ Degree in Dentistry. Master of Oral Surgery and Implantology. Faculty of Medicine and Dentistry. University of Valencia ${ }^{2}$ Degree in Dentistry. Master of Oral Surgery and Implantology. Professor of Oral Surgery. Cardenal Herrera-CEU University ${ }^{3}$ Degree in Dentistry. Student in the Master of Oral Surgery and Implantology. Faculty of Medicine and Dentistry. University of Valencia

${ }^{4}$ Degree in Dentistry. Master of Oral Surgery and Implantology. Faculty of Medicine and Dentistry. University of Valencia

${ }^{5}$ Associate Professor of Oral Surgery. Faculty of Medicine and Dentistry. University of Valencia

${ }^{6}$ Head Service of Maxillofacial Surgery, University la Fe Hospital, Valencia, Spain
}

Correspondence:

Clínicas Odontológicas

Gascó Oliag 1

46021-Valencia (Spain)

maria.penarrocha@uv.es

Received: 04/03/2010

Accepted: 26/08/2010
Bonet-Coloma C, Minguez-Martinez I, Aloy-Prósper A, Galán-Gil S, Peñarrocha-Diago M, Mínguez-Sanz JM. Pediatric oral ranula: Clinical follow-up study of 57 cases. Med Oral Patol Oral Cir Bucal. 2011 Mar 1;16 (2):e158-62.

http://www.medicinaoral.com/medoralfree01/v16i2/medoralv16i2p158.pdf

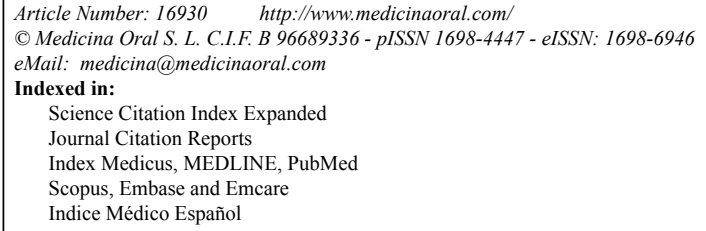

\begin{abstract}
Objective: To present 57 cases of oral ranula in children, analyzing the clinical characteristics, treatment and outcome of these lesions.

Methods: The clinical histories of patients diagnosed with oral ranula, seen between 1998 and 2008 at the Oral and Maxillofacial Surgery Unit of a reference Children's Hospital (0-14 years) were reviewed. All patients with clinical diagnosis of oral ranula were included.

Results: Fifty-seven patients, 21 boys and 36 girls, with a mean age of 5.1 years were included in the study. Thirtytwo cases were located on the left side of the floor of the mouth. The lesion diameter varied between 1 and $3 \mathrm{~cm}$ in 27 cases, 22 were less than $1 \mathrm{~cm}$, and 8 were larger than $3 \mathrm{~cm}$. Fifty-four cases were asymptomatic and 3 ranulas had pain on swallowing. Twenty-two cases were resolved by opening with a tract dilator and 35 by marsupialization. Seven cases recurred at a mean of 12 months after treatment, three of these from the marsupialization group. Conclusion: The majority of the oral ranulas occurred in females, asymptomatic, on the left side of the floor of the mouth, with a mean size of 1 to $3 \mathrm{~cm}$; all lesions were treated by surgery, of which 7 recurred.
\end{abstract}

Key words: Oral ranula, children, treatment. 


\section{Introduction}

Oral ranulas are cystic lesions located on the floor of the mouth that arise from obstruction of the excretory duct of the sublingual gland (1-4). This causes an accumulation of mucoid material, leading to a well-circumscribed swelling in the oral mucosa of the floor of the mouth (5).

Oral ranula is an infrequent pathology $(4,5)$, appearing more frequently in children (1-5). A review of articles published on oral ranula between 2000 and 2009, found only 12 series, of which eight were specific to the pediatric population (Table 1). The largest series corresponded to Chidzonga et al (6) who analyzed 61 oral ranulas in children younger than 10 years. Some authors discuss ranulas in the general population (7-10) and other authors have published isolated clinical cases (1113). It was therefore interesting to analyze oral ranulas in a large sample of pediatric patients of the Oral and Maxi-llofacial Surgery Department of the La Fe University Children's Hospital, Valencia.

The aim is to analyze the clinical characteristics, treatment and outcome of oral ranulas in pediatric patients.

\section{Materials and Methods}

A retrospective clinical study was made, reviewing the clinical history of patients diagnosed with oral ranula,

Table 1. Cases and case series of oral ranulas in children.

\begin{tabular}{|c|c|c|c|c|c|c|}
\hline \multirow[t]{2}{*}{ Author } & \multirow[t]{2}{*}{ Year } & \multirow[t]{2}{*}{ Cases } & \multicolumn{2}{|c|}{ Sex } & \multirow[t]{2}{*}{ Age } & \multirow[t]{2}{*}{ Location } \\
\hline & & & Female & Male & & \\
\hline $\begin{array}{c}\text { Baurmaush } \\
(11)^{*}\end{array}$ & 2002 & 4 & - & - & $>10$ years & - \\
\hline $\begin{array}{c}\text { Morita et al. } \\
\text { (7) }\end{array}$ & 2003 & 9 & 5 & 4 & $6-59$ years & - \\
\hline $\begin{array}{l}\text { Haberal et al. } \\
\qquad(13)^{*}\end{array}$ & 2004 & 16 & 12 & 4 & $\begin{array}{l}17 \text { days- } \\
14 \text { years }\end{array}$ & - \\
\hline $\begin{array}{c}\text { Zhao et al. } \\
\text { (8) }\end{array}$ & 2004 & 571 & 311 & 260 & $\begin{array}{l}3 \text { months- } \\
80 \text { years }\end{array}$ & Left \\
\hline $\begin{array}{c}\text { Yuca et al. } \\
(2)^{*}\end{array}$ & 2005 & 9 & 6 & 3 & $7-15$ years & Left \\
\hline $\begin{array}{l}\text { Lee et al. } \\
(14)^{*}\end{array}$ & 2006 & 13 & 8 & 5 & $6-15$ years & Right \\
\hline $\begin{array}{l}\text { Roh } \\
\text { (9) }\end{array}$ & 2006 & 26 & 15 & 11 & 4-67 years & Right \\
\hline $\begin{array}{l}\text { Zola et al. } \\
(12)^{*}\end{array}$ & 2006 & 1 & 1 & - & 12 years & Left \\
\hline $\begin{array}{l}\text { Sandrini et al. } \\
\text { (10) }\end{array}$ & 2007 & 7 & 3 & 4 & $8-46$ years & - \\
\hline $\begin{array}{c}\text { Garofalo } \\
(5)^{*}\end{array}$ & 2007 & 18 & 9 & 9 & $\begin{array}{l}2 \text { months- } \\
15 \text { years }\end{array}$ & - \\
\hline $\begin{array}{c}\text { Chidzonga et } \\
\text { al. } \\
(6)^{*}\end{array}$ & 2007 & 61 & 47 & 36 & $0-10$ years & Left \\
\hline $\begin{array}{l}\text { Zhi et al. } \\
(4)^{*}\end{array}$ & 2008 & 11 & 6 & 5 & $\begin{array}{l}3 \text { days-3 } \\
\text { months }\end{array}$ & - \\
\hline
\end{tabular}

*series specific to the pediatric population. 
seen between 1988 and 2008 at the Oral and Maxillofacial Surgery Service, La Fe Children's Hospital, Valencia (age 0-14 years).

All patients with a clinical diagnosis of oral ranula were included. Patients with incomplete history were excluded.

Data were collected regarding age, sex, location (left, right), size of lesion (equal to or less than $1 \mathrm{~cm}$, between 1 and $3 \mathrm{~cm}$ and greater than $3 \mathrm{~cm}$ ), symptoms (pain present or absent, discomfort during swallowing), duration (time from when the lesion first appeared to diagnosis (months), treatment (lacrimal dilator or marsupialization), histopathological diagnosis, length of follow-up (from diagnosis to release or last review), and recurrence.

A descriptive analysis was performed for each of the variables, and correlation determined using the chisquare test. Statistical significance was considered for values of $\mathrm{p} \leq 0.05$.

\section{Results}

Seventy-five clinical histories of children with clinical diagnosis of oral ranula were reviewed; 18 were excluded for incomplete information. The study included 57 patients with one oral ranula in each patient, and a mean age of 5.1 years (range 53 days to 12 years). Ten cases were diagnosed before one year of age, and there were no congenital ranulas (Table 2). Twenty-one oral ranulas were found in boys and 36 in girls.

Twenty-five ranulas were located on the right side (Figure 1a) and 32 on the left (Figs 1b, 1c, 1d).

Ranulas ranged from 0.5 to $3.3 \mathrm{~cm}$ in size. The diameter varied between 1 and $3 \mathrm{~cm}$ in 27 cases, 22 were less than $1 \mathrm{~cm}$, and 8 were larger than $2 \mathrm{~cm}$.

Fifty-four cases were asymptomatic. Three cases referred discomfort and pain during swallowing; these three cases were around $3 \mathrm{~cm}$ in diameter.

The mean duration was 2.1 months (range 2 days to 2 years). Of the 57 ranulas, 22 were resolved by breaking

Table 2. Characteristics of the sample of patients in the first year of life.

\begin{tabular}{|c|c|c|c|c|c|c|c|}
\hline Case & Sex & Age & Location & $\begin{array}{l}\text { Size } \\
(\mathrm{cm})\end{array}$ & $\begin{array}{l}\text { Duration } \\
\text { (months) }\end{array}$ & $\begin{array}{l}\text { Follow-up } \\
\text { (Months) }\end{array}$ & Recurrence \\
\hline 1 & $\mathrm{~F}$ & 5 months & Bilateral & $0,5 \times 0,5$ & 1 & 15 & No \\
\hline 2 & $\mathrm{M}$ & 2 months & Right & $1 \times 1$ & 1 & 3 & No \\
\hline 3 & $\mathrm{M}$ & 13 days & Right & $0,5 \times 0,5$ & 15 days & 3 & No \\
\hline 4 & $\mathrm{M}$ & 3 months & Left & $1 \times 0,5$ & 1 & 3 & No \\
\hline 5 & $\mathrm{M}$ & 53 days & Left & $0,5 \times 0,5$ & 1 & 3 & No \\
\hline 6 & $F$ & 3 months & Right & $0,5 \times 1$ & 15 days & 12 & No \\
\hline 7 & $\mathrm{~F}$ & 7 months & Right & $1 \times 1$ & 3 & 3 & $\mathrm{Si}$ \\
\hline 8 & $\mathrm{~F}$ & 6 months & Left & $1 \times 0,7$ & 2 days & 3 & No \\
\hline 9 & $\mathrm{M}$ & 4 months & Right & $0,5 \times 0,5$ & 2 & 3 & No \\
\hline 10 & $\mathrm{M}$ & 9 months & Right & $1 \times 0,5$ & 1 & 9 & No \\
\hline
\end{tabular}

M: Male

F: Female 


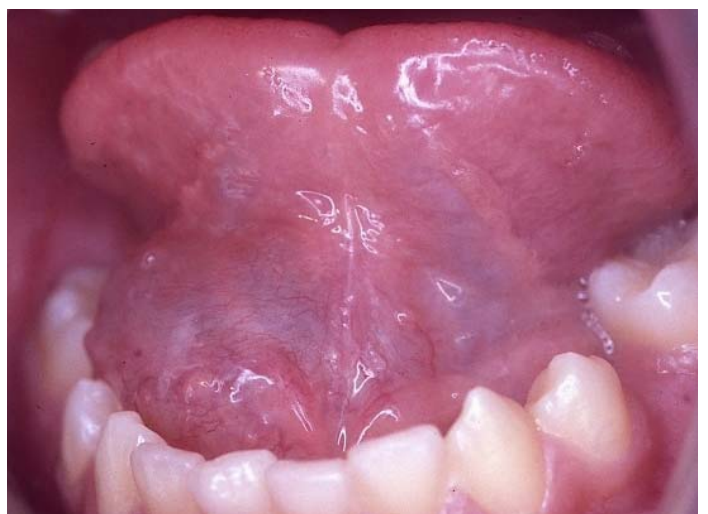

Fig. 1. A) Right side.

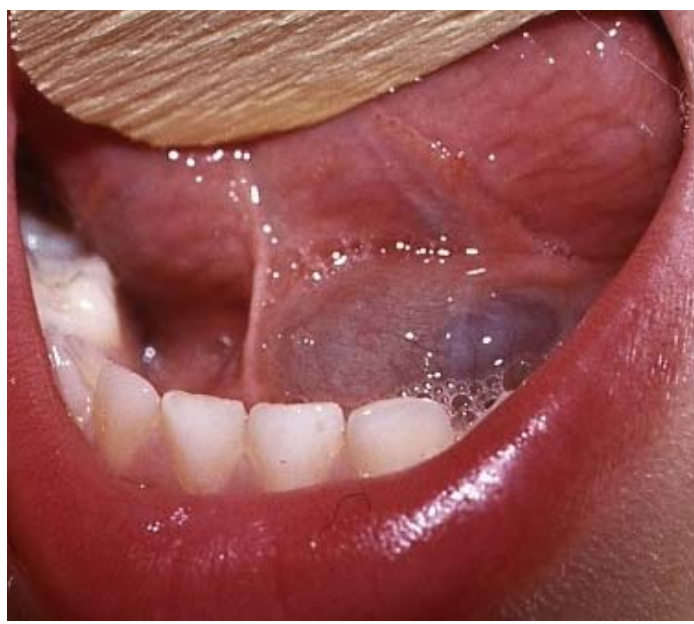

Fig. 1. C) Left side.

the epithelium with a lacrimal dilator, and 35 were extirpated by marsupialization.

Regarding age and size of lesions, it was observed that patients with oral ranulas of $1 \mathrm{~cm}$ or less corresponded significantly with the patients in the first year of life (chi-square, $\mathrm{p}=0.032$ ); lesions greater than $1 \mathrm{~cm}$ were found mainly in older patients, this difference was not statistically significant (chi-square, $\mathrm{p}=0.061$ ).

On relating size and treatment, it was observed that patients with oral ranulas $1 \mathrm{~cm}$ or less in size corresponded to patients treated by breaking the epithelium of the ranula with a lacrimal tract dilator, but without statistical significance (chi-square, $p=0.053$ ), and lesions greater than $1 \mathrm{~cm}$ were treated primarily by marsupialization, this difference was statistically significant (chi-square, $\mathrm{p}=0.027$ ).

The histopathological analysis of lesions treated with marsupialization revealed that all were retention lesions.

The mean follow-up was 6.8 months (range 3 to 15 months). At a mean of 12 months after treatment seven recurrences were observed, three of these had been treated by marsupialization.

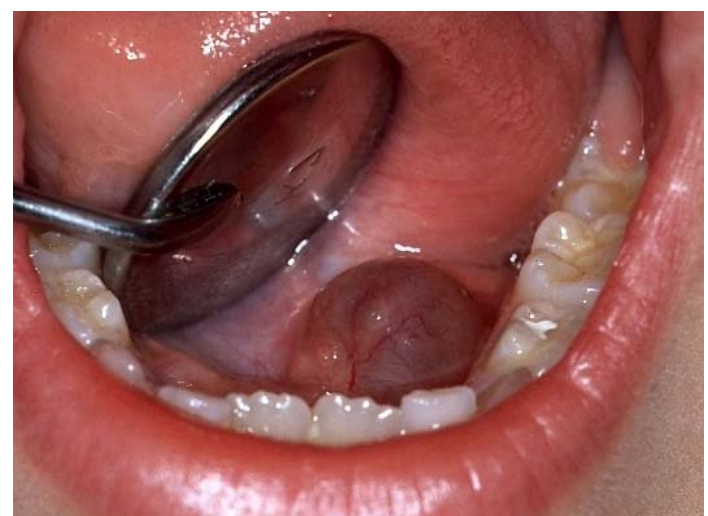

Fig. 1. B) Left side.

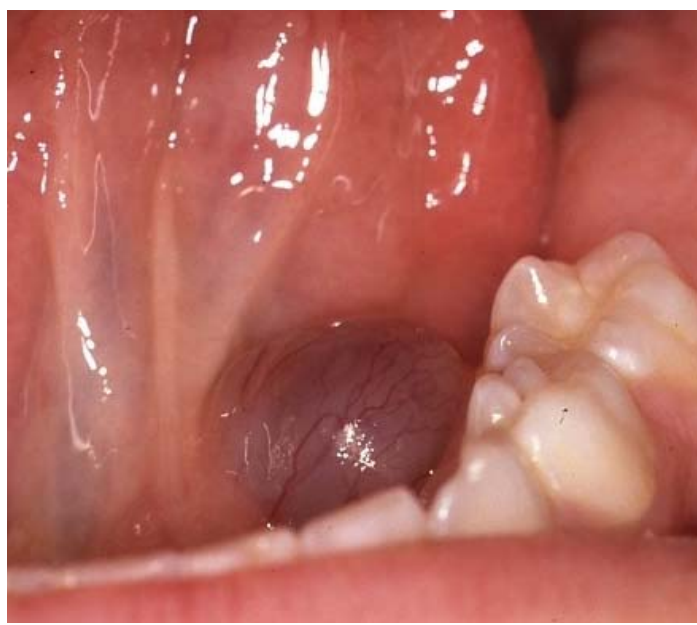

Fig. 1. D) Left side.

\section{Discussion}

Oral ranula is an infrequent pathology $(4,5)$, usually occurring in children and adolescents $(1-5,8)$. Eight series specific to children ( $0-14$ years) have been published (Table 1). This study presents 57 ranulas. Gul et al. (3) estimate the incidence of congenital ranula at $0.74 \%$, in this study there were no ranulas present at birth.

According to most authors oral ranulas predominate in females (2-4, 7-9, 13-15). Chidzonga et al. (6), in a study of 61 ranulas, found 47 in females. In this study, 36 of 57 lesions were in females.

According to the literature $(2,16)$, the most common site of oral ranula is on the left side of the floor of the mouth (4). In this study, 32 ranulas were in this location.

Oral ranulas range from 0.5 to $3.3 \mathrm{~cm}$. in diameter $(17,18)$. In this study 27 ranulas were $1-3 \mathrm{~cm}$ in diameter. Eight lesions were greater than $3 \mathrm{~cm}$ in diameter.

Ranulas are generally asymptomatic, although large ranula can cause aesthetic and functional problems (18). In this study, 54 were asymptomatic. However, three patients presented pain and discomfort during swallowing; these 3 cases exceeded $3 \mathrm{~cm}$ in diameter.

According to the literature, the treatment of choice is 
surgical excision $(2,4,8,14)$, frequently by marsupialization $(17,18)$. Complications of this type of surgery include injury to Wharton's duct, obstruction of the sublingual gland, lingual nerve injury, sensory impairment of the tongue, recurrence and the development of a cervical ranula $(4,15-17,18)$. In this study, all lesions were treated by surgery, 22 were resolved by breaking the epithelium with a lacrimal tract dilator, and 35 were marsupialized.

The recurrence rate of oral ranula is related to the surgical procedure (6). Conventional marsupialization has a higher recurrence rate according to authors (add names of authors) $(8,13,18)$. In the present study, there were 7 recurrences, appearing at a mean of 12 months after treatment, three from the marsupialization group.

In our opinion, complete removal of a ranula is technically very difficult to achieve as it involves an extremely fine mucosa that will usually rupture on excision. The most ideal treatment is therefore marsupialization.

\section{References}

References with links to Crossref - DOI

1. Onderoglu L, Saygan-Karamürsel B, Deren O, Bozdag G, Tekşam O, Tekinalp G. Prenatal diagnosis of ranula at 21 weeks of gestation. Ultrasound Obstet Gynecol. 2003;22:399-401.

2. Yuca K, Bayram I, Cankaya H, Caksen H, Kiroğlu AF, Kiriş M. Pediatric intraoral ranulas: an analysis of nine cases. Tohoku J Exp Med. 2005;205:151-5.

3. Gul A, Gungorduk K, Yildirim G, Gedikbasi A, Ceylan Y. Prenatal diagnosis and management of a ranula. J Obstet Gynaecol Res. 2008;34:262-5.

4. Zhi K, Wen Y, Ren W, Zhang Y. Management of infant ranula. Int J Pediatr Otorhinolaryngol. 2008;72:823-6.

5. Garofalo S, Briganti V, Cavallaro S, Pepe E, Prete M, Suteu L, et al. Nickel Gluconate-Mercurius Heel-Potentised Swine Organ Preparations: a new therapeutical approach for the primary treatment of pediatric ranula and intraoral mucocele. Int J Pediatr Otorhinolaryngol. 2007;71:247-55.

6. Chidzonga MM, Mahomva L. Ranula: experience with 83 cases in Zimbabwe. J Oral Maxillofac Surg. 2007;65:79-82.

7. Morita Y, Sato K, Kawana M, Takahasi S, Ikarashi F. Treatment of ranula--excision of the sublingual gland versus marsupialization. Auris Nasus Larynx. 2003;30:311-4.

8. Zhao YF, Jia Y, Chen XM, Zhang WF. Clinical review of 580 ranulas. Oral Surg Oral Med Oral Pathol Oral Radiol Endod. 2004;98:281-7.

9. Roh JL. Primary treatment of ranula with intracystic injection of OK-432. Laryngoscope. 2006;116:169-72.

10. Sandrini FA, Sant'ana-Filho M, Rados PV. Ranula management: suggested modifications in the micro-marsupialization technique. J Oral Maxillofac Surg. 2007;65:1436-8.

11. Baurmash HD. Treating oral ranula: another case against blanket removal of the sublingual gland. Br J Oral Maxillofac Surg. 2001;39:217-20.

12. Zola M, Rosenberg D, Anakwa K. Treatment of a ranula using an Er,Cr:YSGG laser. J Oral Maxillofac Surg. 2006;64:823-7.

13. Haberal I, Göçmen H, Samim E. Surgical management of pediatric ranula. Int J Pediatr Otorhinolaryngol. 2004;68:161-3.

14. Lee HM, Lim HW, Kang HJ, Chae SW, Hwang SJ, Jung KY, et al. Treatment of ranula in pediatric patients with intralesional injection of OK-432. Laryngoscope. 2006;116:966-9.
15. McGurk M, Eyeson J, Thomas B, Harrison JD. Conservative treatment of oral ranula by excision with minimal excision of the sublingual gland: histological support for a traumatic etiology. J Oral Maxillofac Surg. 2008;66:2050-7.

16. Zhao YF, Jia J, Jia Y. Complications associated with surgical management of ranulas. J Oral Maxillofac Surg. 2005;63:51-4.

17. Baurmash HD. A case against sublingual gland removal as primary treatment of ranulas. J Oral Maxillofac Surg. 2007;65:117-21.

18. McGurk M. Management of the ranula. J Oral Maxillofac Surg. 2007;65:115-6. 